\title{
How to apply clinical cases and medical literature in the framework of a modified "failure mode and effects analysis" as a clinical reasoning tool - an illustration using the human biliary system
}

Kam Cheong Wong ${ }^{1,2,3}$

\begin{abstract}
Background: Clinicians use various clinical reasoning tools such as Ishikawa diagram to enhance their clinical experience and reasoning skills. Failure mode and effects analysis, which is an engineering methodology in origin, can be modified and applied to provide inputs into an Ishikawa diagram.

Method: The human biliary system is used to illustrate a modified failure mode and effects analysis. The anatomical and physiological processes of the biliary system are reviewed. Failure is defined as an abnormality caused by infective, inflammatory, obstructive, malignancy, autoimmune and other pathological processes. The potential failures, their effect(s), main clinical features, and investigation that can help a clinician to diagnose at each anatomical part and physiological process are reviewed and documented in a modified failure mode and effects analysis table. Relevant medical and surgical cases are retrieved from the medical literature and weaved into the table.

Results: A total of 80 clinical cases which are relevant to the modified failure mode and effects analysis for the human biliary system have been reviewed and weaved into a designated table. The table is the backbone and framework for further expansion. Reviewing and updating the table is an iterative and continual process. The relevant clinical features in the modified failure mode and effects analysis are then extracted and included in the relevant Ishikawa diagram.

Conclusions: This article illustrates an application of engineering methodology in medicine, and it sows the seeds of potential cross-pollination between engineering and medicine. Establishing a modified failure mode and effects analysis can be a teamwork project or self-directed learning process, or a mix of both. Modified failure mode and effects analysis can be deployed to obtain inputs for an Ishikawa diagram which in turn can be used to enhance clinical experiences and clinical reasoning skills for clinicians, medical educators, and students.
\end{abstract}

\section{Main text}

Clinicians, medical educators, and medical students use various clinical reasoning tools such as Ishikawa diagram (which is also known as "cause-and-effect diagram") to enhance their clinical experience and reasoning skills. The methodology of applying an Ishikawa diagram in a clinical setting is illustrated in another article [1]. The methods that can be applied to gather information for an Ishikawa

\footnotetext{
Correspondence: kam.wong@sydney.edu.au

'Bathurst Rural Clinical School, Western Sydney University, Bathurst, NSW, Australia

${ }^{2}$ School of Rural Health, University of Sydney, Orange, NSW, Australia
}

Full list of author information is available at the end of the article diagram include brain storming, focus group discussion, interview, survey, and literature searches and review are discussed in a book chapter [2]. This article illustrates how to modify and apply failure mode and effects analysis (FMEA) to provide inputs into an Ishikawa diagram which in turn can be used as a clinical reasoning tool.

FMEA is a tool developed by engineers to systematically assess a complex design or process in order to identify elements that have a risk of failure [3]. In the late 1940s, FMEA was established and deployed by reliability engineers to identify potential failures in military systems [4]. 
Simplistically, the FMEA approach includes a meticulous study on the mode or mechanism by which a failure may occur and the effect(s) that it may cause. The severity of the effect $(\mathrm{S})$, the probability of a failure occurring $(\mathrm{O})$, and the probability that the failure would not be detected (D), are computed or estimated. Then, a risk priority number (RPN) is calculated by multiplying S, O, and D. The RPN is then used to prioritize the remedial and/or preventive measures. The FMEA approach is an ongoing iterative process. It should be updated when there is a change in the process or design, or when there is a failure or when a near-miss failure occurs. The ultimate objective of an FMEA is to provide a platform for the prevention, or at least reduce the likelihood and improve the detection, of failure in a system.

How can I relate this engineering approach to an application in medicine? In this article, failure is defined as an abnormality caused by infective, inflammatory, obstructive, malignancy, autoimmune and other pathological processes. I may not be able to relate the FMEA approach to the entirety of a complex human being with multidimensional complexities including psychosocial components, when an individual presents with a clinical manifestation (that is, a "failure"). Nonetheless, I am illustrating an application of the FMEA approach to a specific subsystem in a human. The "design or anatomy" of a human body and its underlying physiological processes have a potential risk of failing at its various parts anatomically and physiologically. The effect(s) of the failure could be manifested as clinical features (symptoms and signs). The severity, occurrence, and detection of the failure are complex and difficult to be estimated to compute a RPN. Hence, I am excluding RPN in this FMEA approach which I call a "modified FMEA" (in short, mFMEA). The ultimate objective of mFMEA is to provide a methodology to clinicians, medical educators, and medical students, to integrate in their clinical reasoning process and to deploy relevant clinical cases to set the scenario for teaching and learning a specific topic.

The mFMEA approach is applicable for general practitioners (GPs)/family physicians, specialists in various fields (internal medicine, surgery, emergency, intensive care, and so on), medical educators, and medical students. The bottom line is that a patient will always present with symptoms and signs (clinical features or syndromes) that need to be analyzed and put in perspective in an individualized context. An experienced clinician such as a physician or specialist may reach a spot diagnosis or provisional diagnosis, and manage the patient accordingly in a reasonably efficient timeframe. In an experienced diagnostician, the clinical reasoning and diagnostic skill seem to have become second nature to him/her, and the skills may not be explicit to an observer. However, a junior clinician or medical student may start from the first principle to work out a list of differential diagnoses using various clinical reasoning tools such as brain storming, mind mapping, and the Ishikawa diagram/fishbone diagram or cause-and-effect diagram [1]. For example, if a patient presents with a main complaint of pain in the right upper quadrant (RUQ) of the abdomen, a clinician will have a list of differential diagnoses including cholecystitis, cholelithiasis, hepatitis, peptic ulcer, pancreatitis, and referred pain. These can be illustrated in an Ishikawa diagram (Fig. 1) which is subject to ongoing update. The Ishikawa diagram comprises "gastroenterology", "other systems", and "miscellaneous". The biliary system is a branch under "gastroenterology". The Ishikawa diagram will be continually expanded and refined based on other associated symptoms in the individualized context of the patient. Then, one may ask how a mFMEA approach would fit in a clinical setting. A mFMEA can provide inputs into an Ishikawa diagram. Once you have listed the common causes in an Ishikawa diagram via brainstorming, discussion, or self-directed learning process, you turn to mFMEA to explore the potential causes of the human biliary system (Fig. 1). I would like to elaborate this in the following paragraphs.

An English scientist, Richard Dawkins, once said, "Biology is the study of complicated things that have the appearance of having been designed with a purpose." The notable quote underpins many biological and physiological processes within a human body; for example, the human biliary system. When we review the anatomical and physiological processes of the biliary system, we should ask "what is the potential failure and its effect(s)", "the associated main clinical features", and "investigations that can help a clinician to diagnose" at each anatomical part and physiological process, and document them in a mFMEA table (Table 1). The mFMEA table comprises six columns: "Anatomy and physiology", "Potential failure or pathophysiological process", "Effects of the failure", "Main clinical features (symptoms and signs)", "Investigation", and "Note". We can start with common knowledge found in the medical literature, and then proceed to search and extract the relevant medical and surgical cases (generally known as clinical cases in this article) to fill the mFMEA table. Establishing a mFMEA can be a teamwork project or a self-directed learning process, or a mix of teamwork followed by self-directed learning to continually update it.

For example, the human biliary system is used for illustration (Table 1). Firstly, review the major anatomy and physiology of the biliary system, and list them in the first column. The anatomical figure of the biliary system (Fig. 2) will be helpful to provide visual cues to the physiological process. At each anatomical part or physiological process, we should explore what can be the potential failure or pathophysiological process, the corresponding effect(s), the resulting clinical features (symptoms and signs), investigation that can help a clinician to diagnose (in addition 


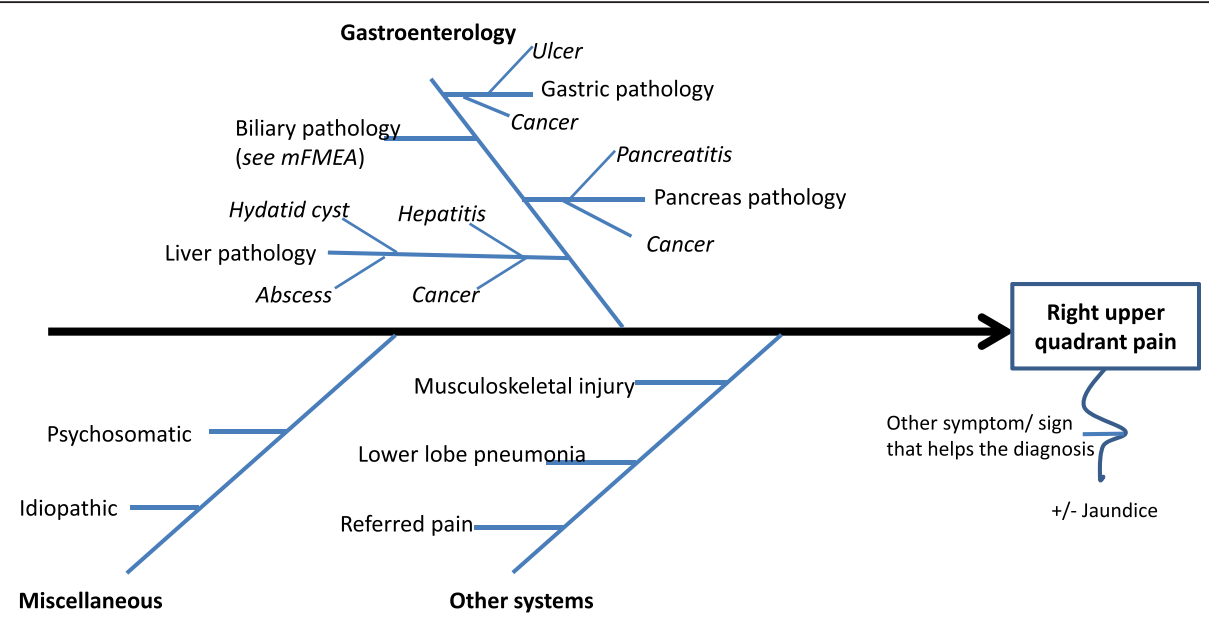

Fig. 1 An Ishikawa diagram for a main presenting complaint of "abdominal pain in the right upper quadrant". mFMEA modified failure mode and effects analysis

to the patient's clinical history and physical examination), and special note. The treatment is not included in the table because the treatment option is dependent on the context of each individual. The note column is used for highlighting a key message or reminder, for example the authors of the case of clonorchiasis encourage clinicians to consider clonorchiasis or opisthorchiasis infection a possible diagnosis for all undiagnosed abdominal pain because the infection has the propensity to cause hepatic fibrosis, liver cancer and cholangiocarcinoma [5]. Also, the "note" column can be used to record citation of relevant new or additional cases (see Table 1).

Let us walk through the steps to establish a mFMEA in Table 1. You may refer to Table 1 and the references for citations of the relevant cases. Starting from the gallbladder, we have already known its common "potential failures" such as cholecystitis, cholecystolithiasis, and gallbladder cancer. By searching the medical literature, I have found some other failures such as gallbladder perforation, herniation, and torsion. The associated effects of the failures include obstruction, necrosis, and hernia. The main clinical features range from asymptomatic to abdominal pain with or without jaundice. The relevant investigations include abdominal ultrasound, computed tomography $(\mathrm{CT})$ scan, endoscopic retrograde cholangiopancreatography (ERCP), and magnetic resonance cholangiopancreatography (MRCP).

In the cystic duct and common bile duct, obstruction (caused by gallstone or cancer) and infection are two common potential failures. In the hepatic duct (intrahepatic and extrahepatic duct), the potential failures include obstruction, infection, abscess, cancer, congenital-related abnormality, for example Caroli's disease (congenital dilatation of the intrahepatic bile ducts), choledochal cyst, and biliary atresia, immune-mediated destruction of the intrahepatic bile ducts (primary biliary cirrhosis), intense inflammatory fibrosis of the intrahepatic and extrahepatic bile ducts (primary sclerosing cholangitis), immunoglobulin G4 (IgG4)-related cholangitis, and abnormality in the genes encoding for the bile canaliculi formation (progressive familial intrahepatic cholestasis). In addition to abdominal pain with or without jaundice, other symptoms and signs include systemic features such as fever, nausea, vomiting, anorexia, weight loss, anemia, fatigue, pruritus, steatorrhea, dark urine, and hepatosplenomegaly. Other investigations include liver function test, liver biopsy, antimitochondrial antibody, and serum IgG4 level according to the context of the patient.

In the process of bile synthesis, conjugation, and transport, the potential failures are broadly categorized into Gilbert syndrome, Crigler-Najjar syndrome, DubinJohnson syndrome, and Rotor syndrome. The clinical features range from asymptomatic to abdominal pain with or without jaundice. The investigations include special genetic tests, liver biopsy, and urinary coproporphyrin level, and plasma sulfobromophthalein depending on the clinical history of the patient.

Other anatomical parts that relate to the biliary system include portal vein, hepatic artery, hepatic vein, sphincter of Oddi, ampulla of Vater, and the pancreas. The potential failures include iatrogenic injury from surgical procedure, thrombosis, spasm, stenosis, and cancer. The clinical features include Courvoisier sign, legs edema, ascites, fatigue, anorexia, weight loss, abdominal pain, and jaundice. Special investigations include Doppler ultrasound of the suprahepatic and cava veins, abdominal CT and angiography, and sphincter of Oddi manometry. 
Table 1 A modified failure mode and effects analysis of the human biliary system

Anatomy and Potential failure/ Effects of the failure

\begin{tabular}{ll}
\hline $\begin{array}{l}\text { Anatomy and } \\
\text { physiology }\end{array}$ & $\begin{array}{l}\text { Potential failure/ } \\
\text { pathophysiological process }\end{array}$ \\
\hline Gallbladder & $\begin{array}{l}\text { Cholecystolithiasis (stones } \\
\text { in the galllbladder) [6] } \\
\text { Cholecystitis - usually associated } \\
\text { with obstruction of the outlet } \\
\text { of the gallbladder by a gallstone [6] }\end{array}$ \\
& \\
& $\begin{array}{l}\text { Cholecystitis associated with } \\
\text { gallbladder torsion (unusual } \\
\text { but critical) [7] }\end{array}$
\end{tabular}

$$
\text { but critical) [7] }
$$

Effects of the failure $\quad \begin{aligned} & \text { Main clinical features } \\ & \text { (symptoms and signs) }\end{aligned}$

Investigation $^{\text {a }}$

Note

Malignancy - e.g. adenocarcinoma [8]

Non-obstructive [6]

The obstruction results in

Asymptomatic [6]

Abdominal X-ray and

inflammation of the

Murphy's sign [6]

AT [6]

gallbladder, and may be

complicated by secondary

bacterial infection [6]

Torsion of the gallbladder

around the cystic duct caused

necrotic gallbladder [7]

\section{The gallbladder tumor invaded} adjacent structures, caused

acute and chronic cholecystitis

with cholelithiasis and

choledochoduodenal fistula [8]

Perforation - acute on chronic gallbladder inflammation possibly due to ischemia and bile stasis secondary to preoperative fasting [9]. Perforation - other causes can be Epstein-Barr virus [10], liver abscess [11], blunt abdominal trauma [12], and spontaneous [13]

Gallbladder herniation: parastomal [14-18], incisional [19-21], spontaneous ventral [22, 23], epigastric [24], transdiaphragmatic herniation [25]

Gallbladder torsion [17]

A gallstone enters via the Vater papilla and later increases in size [29]

Bile leaked into the peritoneum [9]

A midline abdominal hernia with small bowel loops, and a parastomal hernia containing the gallbladder [14]

Torsion of the neck of the gallbladder with secondary suppuration leading to gangrenous changes in the gallbladder [17]

Transition of a gallstone in the gastrointestinal tract leading to mechanical bowel obstruction (gallstone ileus) [29]

Biliary-enteric fistula e.g. gallbladder- "Spontaneous biliary fistulas have duodenal fistula [8]

Failure of the cystic bud to develop in utero [32] been associated with gallbladder cancer; if they are the cause of cancer, or acomplication of it,
this has not yet been defined." [8]

Gallbladder agenesis [32]
Acute onset abdominal pain in the RUQ, with nausea and malaise [7]

1-month history of episodic nausea and vomiting, and epigastric pain on admission [8]

Umbilical pain and a bluish discoloration of the skin around a known umbilical hernia presumably due to tracking of bile within the abdomen [9]

Abdominal pain [14]

Abdominal pain [17]

Nausea, vomiting and abdominal pain [29]

1-month history of episodic nausea and vomiting, and epigastric pain on admission [8]

Reduced appetite, unintentiona weight loss, and a history of fatty food intolerance [32]
Abdominal ultrasound [6]

Abdominal ultrasound

and CT [7]

Abdominal ultrasound,

$C T$, barium study [8]

Liver function test, laparotomy [9]

The patient had spontaneous acalculous gallbladder perforation [9]. This condition is rare but critical

CT scan with oral Gastrograffin (sodium diatrizoate and meglumine diatrizoate) contrast [14]

Abdominal CT [17]

Other case of gallbladder torsion [26], a new case of gallbladder torsion withi an incisional hernia [27], complete gallbladder torsion [28], gallbladder torsion caused acute cholecystitis [7]

Abdominal CT, MRCP [29]

Other case: gallbladder-colon fistula [30] and cholecystogastric fistula [31]

Abdominal ultrasound,

$\mathrm{CT}$, barium study [8]

Abdominal ultrasound, CT, ERCP; preoperative MRCP should be considered in cases in which ultrasound of the gallbladder [32] 
Table 1 A modified failure mode and effects analysis of the human biliary system (Continued)

\begin{tabular}{|c|c|c|c|c|}
\hline $\begin{array}{l}\text { Anatomy and } \\
\text { physiology }\end{array}$ & $\begin{array}{l}\text { Potential failure/ } \\
\text { pathophysiological process }\end{array}$ & Effects of the failure & $\begin{array}{l}\text { Main clinical features } \\
\text { (symptoms and signs) }\end{array}$ & Investigation $^{a}$ \\
\hline \multirow[t]{3}{*}{ Cystic duct } & $\begin{array}{l}\text { Obstruction such as due to } \\
\text { gallstone; chronic obstruction } \\
\text { due to other causes [33] }\end{array}$ & $\begin{array}{l}\text { Hydropic gallbladder - accumulation } \\
\text { of mucus in the distended } \\
\text { gallbladder [33] }\end{array}$ & Abdominal pain in the RUQ [33] & $\begin{array}{l}\text { Abdominal ultrasound } \\
\text { and MRI [33] }\end{array}$ \\
\hline & $\begin{array}{l}\text { Cystic duct obstruction (+/- cystic } \\
\text { artery strangulation) due to torsion } \\
\text { of the neck of the gallbladder [34] }\end{array}$ & $\begin{array}{l}\text { Leading to mural ischemia/ } \\
\text { gallbladder becomes gangrenous, } \\
\text { and may perforate [34] }\end{array}$ & $\begin{array}{l}\text { Epigastric pain with involuntary } \\
\text { guarding and rebound tenderness } \\
\text { in the epigastrium and RUQ [34] }\end{array}$ & $\begin{array}{l}\text { Abdominal ultrasound } \\
\text { and CT [34] }\end{array}$ \\
\hline & $\begin{array}{l}\text { Cystic duct infection e.g. } \\
\text { streptococcal infection [36] }\end{array}$ & $\begin{array}{l}\text { Streptococcal toxic shock } \\
\text { syndrome; local necrosis in } \\
\text { the cystic duct due to } \\
\text { microcirculatory failure } \\
\text { as a result of hypoperfusion } \\
\text { and microthrombosis leading } \\
\text { to perforation of the cystic } \\
\text { duct [36] }\end{array}$ & $\begin{array}{l}\text { Abdominal tenderness, rash } \\
\text { and fever after an episode } \\
\text { of pharyngitis* [36] }\end{array}$ & $\begin{array}{l}\text { Liver function test, } \\
\text { abdominal ultrasound } \\
\text { and } \mathrm{CT}\end{array}$ \\
\hline \multirow[t]{4}{*}{$\begin{array}{l}\text { Common bile } \\
\text { duct }\end{array}$} & $\begin{array}{l}\text { Choledocholithiasis (stones in } \\
\text { the common bile duct) [6] }\end{array}$ & Non-obstructive [6] & Asymptomatic [6] & ERCP [6] \\
\hline & Infection: bacterial [38] & Cholangitis [38] & $\begin{array}{l}\text { Charcot's triad (abdominal pain, } \\
\text { fever and jaundice), nausea, and } \\
\text { dark urine [38] }\end{array}$ & $\begin{array}{l}\text { Ultrasound biliary tree, } \\
\text { ERCP [38] }\end{array}$ \\
\hline & $\begin{array}{l}\text { Infection: liver flukes from } \\
\text { consumption of undercooked } \\
\text { contaminated seafood [5] }\end{array}$ & $\begin{array}{l}\text { The metacercariae then excyst and } \\
\text { migrate to the bile duct where } \\
\text { they mature; prolonged infection } \\
\text { may result in cholangiocarcinoma [5] }\end{array}$ & $\begin{array}{l}\text { Abdominal pain, watery stools. } \\
\text { The patients in this case also } \\
\text { had malaria; they also had } \\
\text { malaria-like symptoms (fever, } \\
\text { headache) [5] }\end{array}$ & $\begin{array}{l}\text { Microscopy examination } \\
\text { after staining the stools } \\
\text { with Giemsa or Ziehl- } \\
\text { Neelsen stains [5] }\end{array}$ \\
\hline & $\begin{array}{l}\text { Bleeding from the biliary tree is } \\
\text { usually associated with trauma } \\
\text { (can be iatrogenic), cholelithiasis, } \\
\text { vascular disorders, tumors [39] }\end{array}$ & $\begin{array}{l}\text { Hemobilia; tumor invasion into the } \\
\text { intrahepatic bile duct, the tumor may } \\
\text { rupture into the biliary system }[39,40]\end{array}$ & $\begin{array}{l}\text { Hematemesis and epigastric } \\
\text { pain [39] }\end{array}$ & $\begin{array}{l}\text { Abdominal CT [39] Multislice } \\
\mathrm{CT} \text { angiography is increasingly } \\
\text { being used in the } \\
\text { investigation [41] }\end{array}$ \\
\hline \multirow[t]{2}{*}{ Hepatic bile duct } & Gallstones [6] & Biliary obstruction [6] & Pain in the RUQ +/- jaundice [6] & $\begin{array}{l}\text { Abdominal ultrasound, } \\
\text { ERCP [6] }\end{array}$ \\
\hline & $\begin{array}{l}\text { Pigmented-stone formation and } \\
\text { bacterial superinfection; Ascaris } \\
\text { lumbricoides and Gram-negative } \\
\text { bacteria consistent with Klebsiella } \\
\text { species [43] "Through the portal } \\
\text { circulation, larvae of Ascaris } \\
\text { lumbricoides migrate from the } \\
\text { stomach or small intestine to } \\
\text { the liver and then to the lungs, } \\
\text { where they break out into the } \\
\text { airspaces, migrate up the trachea, } \\
\text { and are swallowed. The larvae develop } \\
\text { into sexually mature adults in the } \\
\text { small intestine where they live and } \\
\text { lay eggs that pass in the feces." [44] }\end{array}$ & $\begin{array}{l}\text { Hepatolithiasis; inflammation in } \\
\text { portal tracts, often with portal } \\
\text { pylethrombophlebitis; patients } \\
\text { with advanced disease have } \\
\text { chronic lesions characterized by } \\
\text { periductal fibrosis [43] }\end{array}$ & $\begin{array}{l}\text { Recurrent pain in the RUQ of } \\
\text { the abdomen [43] }\end{array}$ & $\begin{array}{l}\text { Liver function test, abdominal } \\
\text { ultrasound, CT, ERCP, MRI, } \\
\text { MRCP, blood cultures, } \\
\text { microscopy examination } \\
\text { on stool specimen [43] }\end{array}$ \\
\hline
\end{tabular}

Note

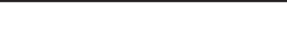

Another case [35]

Refer to the case report for the time-course of the clinical features [36] Another case of cystic duct erforation with acalculous cholecystitis [37]

The authors encourage clinicians to consider clonorchiasis/opisthorchiasis infection a possible diagnosis for all undiagnosed abdominal pain since the infection has propensity to cause hepatic fibrosis, liver cancer and cholangiocarcinoma [5]

Hemobilia may present as upper abdominal pain, gastrointestinal bleeding, and jaundice in some patients (22-38\%) [42]

The 35-year-old patient was born in Vietnam and she immigrated to USA in her early 20s. Multiple large stones in the common bile duct, the left hepatic duct, and the left intrahepatic duct. A wide range of differential diagnoses were discussed in this article [43]. "Obstruction along the pancreatobiliary tree may occur if aberrant migration of larvae or adult worms through the ampulla of Vater occurs." [45] 
Table 1 A modified failure mode and effects analysis of the human biliary system (Continued)

\begin{tabular}{|c|c|c|c|c|c|}
\hline $\begin{array}{l}\text { Anatomy and } \\
\text { physiology }\end{array}$ & $\begin{array}{l}\text { Potential failure/ } \\
\text { pathophysiological process }\end{array}$ & Effects of the failure & $\begin{array}{l}\text { Main clinical features } \\
\text { (symptoms and signs) }\end{array}$ & Investigation $^{a}$ & Note \\
\hline & $\begin{array}{l}\text { Malignancy e.g. hepatocellular } \\
\text { carcinoma [46] }\end{array}$ & $\begin{array}{l}\text { Intrahepatic and extrahepatic bile } \\
\text { duct obstruction [46] }\end{array}$ & $\begin{array}{l}\text { Upper abdominal pain, jaundice } \\
\text { and weight loss; icterus, and } \\
\text { hepatomegaly [46] }\end{array}$ & $\begin{array}{l}\text { Ultrasound and CT } \\
\text { abdomen [46] }\end{array}$ & \\
\hline & $\begin{array}{l}\text { Malignancy in the intrahepatic } \\
\text { biliary duct [47] }\end{array}$ & Intrahepatic cholangiocarcinoma [47] & $\begin{array}{l}\text { Episodic epigastric pain and } \\
\text { iron-deficiency anemia, } \\
\text { jaundice [47] }\end{array}$ & $\begin{array}{l}\text { Liver function test, full blood } \\
\text { examination, iron studies, } \\
\text { abdominal ultrasound, CT, and } \\
\text { ERCP [47] }\end{array}$ & \\
\hline & $\begin{array}{l}\text { Intrahepatic perforated } \\
\text { cholecystitis [11] }\end{array}$ & Intrahepatic abscess [11] & $\begin{array}{l}\text { Intermittent fever, anorexia, and } \\
\text { weight loss [11] }\end{array}$ & $\begin{array}{l}\text { Ultrasound of the liver, } \\
\text { and CT angiogram [11] }\end{array}$ & Other case [48] \\
\hline & Cholesterol hepatolithiasis [49] & $\begin{array}{l}\text { Heterotopic pancreatic tissues were } \\
\text { distributed along the wall of the } \\
\text { biliary tract and were composed } \\
\text { of acinar cells and duct elements } \\
\text { without islets of Langerhans [49] }\end{array}$ & $\begin{array}{l}\text { Abdominal pain }(45.5 \%), \\
\text { epigastric discomfort }(12.0 \%), \\
\text { nausea and vomiting }(9.6 \%), \\
\text { bleeding (8.0\%) }[49]\end{array}$ & $\begin{array}{l}\text { Ultrasound, CT scan, and } \\
\text { definitive diagnosis by } \\
\text { histopathological } \\
\text { examination on the } \\
\text { excised mass, ERCP [49] }\end{array}$ & $\begin{array}{l}\text { The patient in the case was } \\
\text { asymptomatic [49] }\end{array}$ \\
\hline & $\begin{array}{l}\text { Multifocal congenital dilatations } \\
\text { of the intrahepatic bile ducts [50] }\end{array}$ & $\begin{array}{l}\text { Caroli's disease (the dilated } \\
\text { intrahepatic ducts, which may } \\
\text { be diffuse or limited, presenting } \\
\text { in a sack form that produces cystic } \\
\text { structures, which communicate } \\
\text { with the biliary tree) [50] }\end{array}$ & $\begin{array}{l}\text { Asymptomatic in this case [50]. } \\
\text { Others have reported RUQ } \\
\text { abdominal pain, jaundice, and } \\
\text { recurrent cholangitis [51] }\end{array}$ & $\begin{array}{l}\text { Abdominal } C T, M R I, M R C P \text {, } \\
\text { histopathologic findings } \\
\text { on resected liver } \\
\text { specimen [50] }\end{array}$ & \\
\hline & $\begin{array}{l}\text { Obliterative cholangiopathy - } \\
\text { biliary atresia [52] }\end{array}$ & $\begin{array}{l}\text { Neonatal biliary obstruction and } \\
\text { cholestasis [52] }\end{array}$ & Jaundice [52] & $\begin{array}{l}\text { Urinary urobilinogen combined } \\
\text { with GGT; liver biopsy; diagnosis } \\
\text { of biliary atresia was confirmed } \\
\text { by operative cholangiography } \\
\text { and/or laparotomy findings [52] }\end{array}$ & \\
\hline & $\begin{array}{l}\text { Immune-mediated destruction of } \\
\text { the intrahepatic bile ducts [53] }\end{array}$ & $\begin{array}{l}\text { Primary biliary cirrhosis leads to } \\
\text { decreased bile secretion and the } \\
\text { retention of toxic substances within } \\
\text { the liver, resulting in further hepatic } \\
\text { damage, fibrosis, cirrhosis, and } \\
\text { eventually, liver failure [53] }\end{array}$ & $\begin{array}{l}\text { Fatigue and pruritus; unexplained } \\
\text { discomfort in the RUQ of the abdomen; } \\
\text { hepatomegaly; jaundice, portal } \\
\text { hypertension and steatorrhea } \\
\text { may occur in advanced disease; } \\
\text { splenomegaly (uncommon); rarely } \\
\text { ascites, hepatic encephalopathy, or } \\
\text { hemorrhage from esophageal } \\
\text { varices [53] }\end{array}$ & $\begin{array}{l}\text { Antimitochondrial antibodies, } \\
\text { which are present in } 90-95 \% \\
\text { of patients and are often } \\
\text { detectable years before clinical } \\
\text { signs appear; liver enzymes; liver } \\
\text { biopsy [53] }\end{array}$ & \\
\hline & $\begin{array}{l}\text { Intense inflammatory fibrosis of } \\
\text { the intrahepatic and extrahepatic } \\
\text { biliary ducts [54] }\end{array}$ & $\begin{array}{l}\text { Primary sclerosing cholangitis (PSC): } \\
\text { fibrosis involving the common bile } \\
\text { duct, hepatic ducts, and sometimes } \\
\text { the gallbladder; may progress to } \\
\text { secondary biliary cirrhosis [54] }\end{array}$ & $\begin{array}{l}\text { Progressive obstructive jaundice, } \\
\text { pruritus, weight loss, pain (RUQ } \\
\text { or epigastric pain) [54] }\end{array}$ & $\begin{array}{l}\text { Elevation of total and direct } \\
\text { (conjugated) serum bilirubin, } \\
\text { serum alkaline phosphatase } \\
\text { were } 3 \text { to } 5 \text { times normal; } \\
\text { operative cholangiograms [54] }\end{array}$ & $\begin{array}{l}\text { PSC can be associated with } \\
\text { inflammatory bowel disease. Primary } \\
\text { biliary cirrhosis and sclerosing } \\
\text { cholangiocarcinoma should be ruled } \\
\text { out prior to diagnosing PSC [54] }\end{array}$ \\
\hline & $\begin{array}{l}\text { Extensive lgG4-positive plasma } \\
\text { cells and T-lymphocyte infiltration } \\
\text { of various organs including bile } \\
\text { duct and gallbladder [55] }\end{array}$ & $\begin{array}{l}\text { Systemic fibroinflammatory causing } \\
\text { sclerosing cholangitis [55] }\end{array}$ & $\begin{array}{l}\text { Painless jaundice and weight } \\
\text { loss [55] }\end{array}$ & $\begin{array}{l}\text { CT abdomen, liver function } \\
\text { test, serum IgG4; "ERCP with } \\
\text { intraductal ultrasonography } \\
\text { (IDUS), brush cytology and } \\
\text { endobiliary biopsy would be } \\
\text { helpful" [55] }\end{array}$ & $\begin{array}{l}\text { Another recent case reported that } \\
\text { lgG4-related cholangitis is a rather } \\
\text { uncommon cause of biliary obstruction, } \\
\text { which can be easily mistaken for a } \\
\text { cholangiocarcinoma } \\
\text { [56] }\end{array}$ \\
\hline
\end{tabular}


Table 1 A modified failure mode and effects analysis of the human biliary system (Continued)

\begin{tabular}{|c|c|c|c|c|c|}
\hline $\begin{array}{l}\text { Anatomy and } \\
\text { physiology }\end{array}$ & $\begin{array}{l}\text { Potential failure/ } \\
\text { pathophysiological process }\end{array}$ & Effects of the failure & $\begin{array}{l}\text { Main clinical features } \\
\text { (symptoms and signs) }\end{array}$ & Investigation $^{a}$ & Note \\
\hline & $\begin{array}{l}\text { Abnormality in the genes encoding } \\
\text { for canalicular bile formation [57] }\end{array}$ & $\begin{array}{l}\text { Defective bile canaliculi leading to } \\
\text { intrahepatic cholestasis which may } \\
\text { progress to fibrosis and endstage } \\
\text { liver disease (progressive familial } \\
\text { intrahepatic cholestasis) [57] }\end{array}$ & Progressive jaundice [57] & $\begin{array}{l}\text { Radiological, laboratory, and } \\
\text { liver biopsy findings [57] }\end{array}$ & \\
\hline & $\begin{array}{l}\text { Cystic dilatation of extrahepatic } \\
\text { bile ducts, with or without the } \\
\text { dilatation of the intrahepatic } \\
\text { duct [58] }\end{array}$ & Choledochal cyst [58] & $\begin{array}{l}\text { In this case, an antenatal } \\
\text { diagnosis of an abdominal } \\
\text { cyst [58]. Patient can be } \\
\text { asymptomatic [6] }\end{array}$ & $\begin{array}{l}\text { Abdominal ultrasound and } \\
\text { operative cholangiogram [58]. } \\
\text { Liver function test, ERCP, CT } \\
\text { or MRI [6] }\end{array}$ & $\begin{array}{l}\text { Choledochal cyst may be associated } \\
\text { with biliary atresia [59] }\end{array}$ \\
\hline & $\begin{array}{l}\text { Malignancy e.g. SCC at the bifurcation } \\
\text { of the common hepatic duct, and } \\
\text { adenocarcinoma in the common } \\
\text { bile duct [60] }\end{array}$ & $\begin{array}{l}\text { Biliary obstruction leading to } \\
\text { hyperbilirubinemia [60] }\end{array}$ & $\begin{array}{l}\text { Jaundice, dark urine, itch, and } \\
\text { weight loss [60] }\end{array}$ & $\begin{array}{l}\text { Abdominal ultrasound, } C T \text {, } \\
\text { positron emission tomography- } \\
C T[60]\end{array}$ & $\begin{array}{l}\text { Other cases of malignancy at the } \\
\text { common bile duct }[61,62]\end{array}$ \\
\hline \multirow[t]{4}{*}{$\begin{array}{l}\text { Bile synthesis, } \\
\text { conjugation, } \\
\text { transport }\end{array}$} & $\begin{array}{l}\text { Hepatic glucuronidating activity is } \\
\text { reduced [63] }\end{array}$ & $\begin{array}{l}\text { Mild, chronic unconjugated } \\
\text { hyperbilirubinemia } \\
\text { in the absence of } \\
\text { hepatocellular disease or } \\
\text { hemolysis (Gilbert } \\
\text { syndrome) [63] }\end{array}$ & Intermittent mild jaundice [64] & Genetic testing [64] & $\begin{array}{l}\text { Reduced expression of bilirubin } \\
\text { UDP-glucuronosyltransferase } 1 \\
\text { gene; an autosomal recessive } \\
\text { mode of inheritance was } \\
\text { suggested [63] }\end{array}$ \\
\hline & $\begin{array}{l}\text { Deficiency of hepatic glucuronyl } \\
\text { transferase [65] }\end{array}$ & $\begin{array}{l}\text { Hyperbilirubinemia of the } \\
\text { unconjugated type; complication } \\
\text { includes kernicterus (Crigler-Najjar } \\
\text { syndrome) [65] }\end{array}$ & $\begin{array}{l}\text { Jaundice since birth; } \\
\text { hepatomegaly; frequent } \\
\text { generalized, tonic and clonic } \\
\text { convulsions due to } \\
\text { kernicterus [65] }\end{array}$ & $\begin{array}{l}\text { Serum bilirubin (direct/ } \\
\text { conjugated and indirect/ } \\
\text { unconjugated) test, genetic } \\
\text { testing [65] }\end{array}$ & $\begin{array}{l}\text { This disease is inherited as an } \\
\text { autosomal recessive trait [65] }\end{array}$ \\
\hline & $\begin{array}{l}\text { A defect in the canalicular multispecific } \\
\text { organic anion transporter (cMOAT) gene } \\
\text { (ABCC2/MRP2 superfamily) located at } \\
\text { 10q24 [66] }\end{array}$ & $\begin{array}{l}\text { Impaired hepatobiliary transport of } \\
\text { non-bile salt organic anions leading to } \\
\text { chronic conjugated hyperbilirubinemia } \\
\text { (Dubin-Johnson syndrome) [66] }\end{array}$ & $\begin{array}{l}\text { This patient presented with } \\
\text { repeated episodes of jaundice } \\
\text { during illness; other patients } \\
\text { may present with abdominal } \\
\text { pain, fatigue, liver enlargement, } \\
\text { or dark urine [67] [68] }\end{array}$ & $\begin{array}{l}\text { Liver function test, abdominal } \\
\text { ultrasound, liver biopsy showed } \\
\text { presence of parenchymal } \\
\text { pigmentation, urinary } \\
\text { coproporphyrin level, } \\
\text { genetic testing [67] }\end{array}$ & $\begin{array}{l}\text { This is an autosomal recessive } \\
\text { disorder [67] }\end{array}$ \\
\hline & $\begin{array}{l}\text { Homozygous inactivation of two } \\
\text { adjacent genes SLCO1B1 and SLCO1B3 } \\
\text { encoding organic anion transporting } \\
\text { polypeptides OATP1B1 and } \\
\text { OATP1B3 [69] }\end{array}$ & $\begin{array}{l}\text { Chronic conjugated hyperbilirubinemia } \\
\text { without abnormal hepatic pigmentation } \\
\text { (Rotor syndrome) [69, 70]. Abnormal } \\
\text { transfer of sulfobromophthalein from } \\
\text { plasma into the liver [70] }\end{array}$ & Nonhemolytic jaundice [71] & $\begin{array}{l}\text { Urinary coproporphyrin and } \\
\text { plasma sulfobromophthalein, } \\
\text { genetic testing [70] }\end{array}$ & $\begin{array}{l}\text { This is an autosomal recessive } \\
\text { disorder [70] }\end{array}$ \\
\hline Portal vein & $\begin{array}{l}\text { latrogenic injury from surgical } \\
\text { procedure [72] }\end{array}$ & Portal vein thrombosis [72] & $\begin{array}{l}\text { Pain in the RUQ of the } \\
\text { abdomen [72] }\end{array}$ & $\begin{array}{l}\text { Abdominal } \mathrm{CT} \text { and } \\
\text { angiography [72] }\end{array}$ & $\begin{array}{l}\text { Another case of portal vein thrombosis } \\
\text { secondary to hyperhomocysteinemia } \\
\text { with pernicious anemia was } \\
\text { reported [73] }\end{array}$ \\
\hline Hepatic artery & $\begin{array}{l}\text { latrogenic injury from surgical } \\
\text { procedure [72] }\end{array}$ & $\begin{array}{l}\text { Hepatic ischemia [72], unrecognized } \\
\text { vasculobiliary injury (VBI) can lead to } \\
\text { biliary strictures, cholangitis and liver }\end{array}$ & $\begin{array}{l}\text { Pain in the RUQ of the } \\
\text { abdomen [72] }\end{array}$ & $\begin{array}{l}\text { Abdominal } \mathrm{CT} \text { and } \\
\text { angiography [72] }\end{array}$ & \\
\hline
\end{tabular}


Table 1 A modified failure mode and effects analysis of the human biliary system (Continued)

\begin{tabular}{|c|c|c|c|c|c|}
\hline $\begin{array}{l}\text { Anatomy and } \\
\text { physiology }\end{array}$ & $\begin{array}{l}\text { Potential failure/ } \\
\text { pathophysiological process }\end{array}$ & Effects of the failure & $\begin{array}{l}\text { Main clinical features } \\
\text { (symptoms and signs) }\end{array}$ & Investigation $^{a}$ & Note \\
\hline Hepatic vein & $\begin{array}{l}\text { Blood clots completely or partially } \\
\text { block the hepatic veins that carry } \\
\text { blood from the liver into the } \\
\text { inferior vena cava [75] }\end{array}$ & $\begin{array}{l}\text { Hepatic vein thrombosis/Budd-Chiari } \\
\text { syndrome }[75,76]\end{array}$ & $\begin{array}{l}\text { Fatigue, abdominal pain, nausea, } \\
\text { jaundice, hepatosplenomegaly, } \\
\text { edema in the legs, ascites, and } \\
\text { sometimes esophageal } \\
\text { varices [75] }\end{array}$ & $\begin{array}{l}\text { Doppler ultrasound } \\
\text { examination of suprahepatic } \\
\text { and cava veins [76] }\end{array}$ & $\begin{array}{l}\text { Budd-Chiari syndrome is a vascular } \\
\text { complication that can be associated } \\
\text { with Behçet's disease [76] }\end{array}$ \\
\hline $\begin{array}{l}\text { Sphincter of } \\
\text { Oddi }\end{array}$ & $\begin{array}{l}\text { Spasm or stenosis of the sphincter } \\
\text { of Oddi (see note in the last } \\
\text { column) [77] }\end{array}$ & $\begin{array}{l}\text { Sphincter of Oddi dysfunction; } \\
\text { idiopathic recurrent acute } \\
\text { pancreatitis (can be } \\
\text { controversial) [78] }\end{array}$ & $\begin{array}{l}\text { Persistent or unexplained } \\
\text { episodic abdominal pain in } \\
\text { patients following } \\
\text { cholecystectomy [77, 78]. } \\
\text { The symptoms may } \\
\text { precede cholecystectomy [77] }\end{array}$ & $\begin{array}{l}\text { Sphincter of Oddi } \\
\text { manometry [78] }\end{array}$ & $\begin{array}{l}\text { Yaghoobi and Romagnuolo reviewed } \\
\text { recent literature on sphincter of Oddi } \\
\text { dysfunction; little is known about the } \\
\text { etiology of the disease [78] }\end{array}$ \\
\hline Ampulla of Vater & Adenoma at the ampulla [79] & $\begin{array}{l}\text { Lithiasis of the bile duct and chronic } \\
\text { pancreatitis [79] }\end{array}$ & $\begin{array}{l}\text { Icterus/jaundice, } \\
\text { and painless swelling of the } \\
\text { gallbladder (Courvoisier sign) [79] }\end{array}$ & $\begin{array}{l}\text { Abdominal ultrasound, } C T \text {, } \\
\text { ERCP with biopsy of the } \\
\text { lesion [79] }\end{array}$ & $\begin{array}{l}\text { Adenoma has potential for } \\
\text { malignancy [80] }\end{array}$ \\
\hline Pancreas & $\begin{array}{l}\text { Malignancy (e.g. tumor in the } \\
\text { head of pancreas) [6] }\end{array}$ & $\begin{array}{l}\text { The tumor compresses the common } \\
\text { bile duct and pancreatic duct leading } \\
\text { to hyperbilirubinemia [6] }\end{array}$ & $\begin{array}{l}\text { Anorexia, weight loss, upper } \\
\text { abdominal pain, and jaundice [6] }\end{array}$ & Abdominal CT and ERCP [6] & $\begin{array}{l}\text { A recent case of a tumor in the head } \\
\text { of pancreas [81] }\end{array}$ \\
\hline \multirow[t]{3}{*}{$\begin{array}{l}\text { Hematological } \\
\text { process }\end{array}$} & $\begin{array}{l}\text { Red blood cell enzyme (G6PD) } \\
\text { deficiency [82] }\end{array}$ & $\begin{array}{l}\text { The enzyme-deficient red blood cells } \\
\text { are susceptible to hemolysis induced } \\
\text { by certain drugs, bacterial and viral } \\
\text { infections. Excessive hemolysis leads } \\
\text { to increase in unconjugated bilirubin }\end{array}$ & $\begin{array}{l}\text { Jaundice; generalized tonic- } \\
\text { clonic seizure when kernicterus } \\
\text { occurs [82] }\end{array}$ & $\begin{array}{l}\text { Liver function test, serum } \\
\text { G6PD level, G6PD } \\
\text { deficiency phenotyping [82] }\end{array}$ & $\begin{array}{l}\text { G6PD deficiency is an X-linked } \\
\text { recessive disease }\end{array}$ \\
\hline & Paroxysmal nocturnal hemoglobinuria & $\begin{array}{l}\text { Prolonged and recurrent red blood cell } \\
\text { breakdown results in increased bilirubin } \\
\text { in the gallbladder. The excess bilirubin } \\
\text { can precipitate bilirubin stones. } \\
\text { Gallstones in the common bile } \\
\text { duct [83] }\end{array}$ & Jaundice and abdominal pain [83] & CT, ERCP, MRCP [83] & \\
\hline & $\begin{array}{l}\text { Red blood cell membrane defect } \\
\text { resulting in spherical, osmotically } \\
\text { fragile erythrocytes (hereditary } \\
\text { spherocytosis) [84] }\end{array}$ & $\begin{array}{l}\text { Premature red blood cell } \\
\text { destruction leading to } \\
\text { hyperbilirubinemia [84] }\end{array}$ & $\begin{array}{l}\text { Anemia, jaundice, and } \\
\text { splenomegaly [84] }\end{array}$ & $\begin{array}{l}\text { Peripheral blood smear } \\
\text { showed small and dense } \\
\text { spherocytes; osmotic fragility } \\
\text { test [84] }\end{array}$ & $\begin{array}{l}\text { The patient in the case has coexistence } \\
\text { of hereditary spherocytosis and Gilbert } \\
\text { syndrome [84] }\end{array}$ \\
\hline $\begin{array}{l}\text { Endocrinological } \\
\text { process }\end{array}$ & $\begin{array}{l}\text { Poorly controlled diabetes } \\
\text { mellitus [85] }\end{array}$ & $\begin{array}{l}\text { The excess glucose increases } \\
\text { glycogen storage in the liver } \\
\text { and blocks glycogenolysis } \\
\text { resulting in glycogenic } \\
\text { hepatopathy [85] }\end{array}$ & $\begin{array}{l}\text { Hepatomegaly and pain in } \\
\text { the RUQ [85] }\end{array}$ & $\begin{array}{l}\text { Ultrasound abdomen, liver } \\
\text { function test, and liver } \\
\text { biopsy [85] }\end{array}$ & \\
\hline
\end{tabular}

This table is neither exhaustive nor comprehensive. For instance, it has not included drug-induced liver injury, and various infective causes such as hepatitis. It is meant to be a framework for discussion and illustration in this article. It can be deployed and continually updated by clinicians for their own use. In addition to a patient's clinical history and physical examination findings. CT computed tomography, ERCP endoscopic retrograde cholangiopancreatography, G6PD glucose-6-phosphate dehydrogenase, GGT gamma-glutamyltransferase, IDUS intraductal ultrasonography, IgG4 immunoglobulin G4, MRCP magnetic resonance cholangiopancreatography, MRI magnetic resonance imaging, PSC primary sclerosing cholangitis, RUQ right upper quadrant, SCC squamous cell carcinoma, VBI vasculobiliary injury 


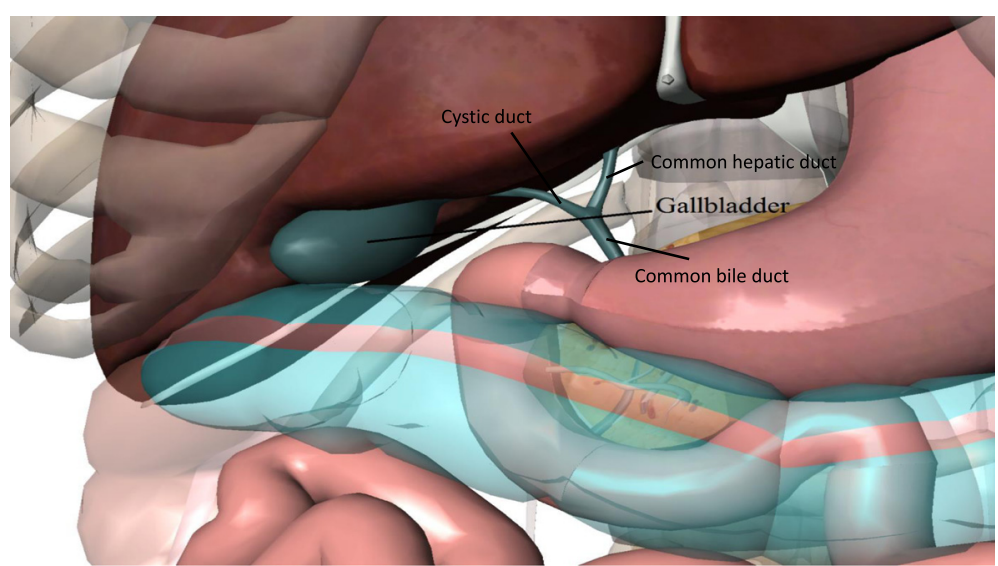

Fig. 2 The human biliary system. Image courtesy of Visible Body (www.visiblebody.com)

The relevant potential failures of the hematological process, which is not restricted to a particular anatomical structure, include glucose-6-phosphate dehydrogenase (G6PD) deficiency, paroxysmal nocturnal hemoglobinuria $(\mathrm{PNH})$, and hereditary spherocytosis. These abnormalities result in excessive hemolysis of red blood cells leading to hyperbilirubinemia. The clinical features include anemia, jaundice, splenomegaly, and kernicterus (in serious cases). The special investigations include serum G6PD level, genetic test, peripheral blood smear, and spherocyte osmotic fragility test.

An example of endocrinological condition has been reported in the New England Journal of Medicine - A patient with poorly controlled diabetes mellitus has excessive glucose in the blood leading to an increase in glycogen storage in the liver and inhibition of glycogenolysis resulting in glycogenic hepatopathy. The condition is manifested as hepatomegaly and pain in the RUQ of the abdomen.

After establishing the mFMEA in Table 1, I can update the relevant Ishikawa diagram for "pain in the RUQ of the abdomen" (Fig. 1) to include the detailed inputs for the "biliary pathology" as shown in Fig. 3.

There are many sources of clinical cases such as:

- Journal of Medical Case Reports

- BMJ Case Reports

- New England Journal of Medicine

- Many other BioMed Central Open Access journals, for example BMC Surgery

How to keep a mFMEA table up to date.

- Set automatic notification when a relevant research or medical case report is published, for example setting a "search alert" in Journal of Medical Case
Reports. This can be easily done by using the advanced search function, perform your search, and save the search history that you want to activate "search alert". You can always go back to your "saved searches" to refine your search algorithm.

- Review an article and evaluate whether it fits into an anatomical or physiological part in a specific mFMEA, for example the biliary system. If a clinical case adds new findings in terms of pathophysiological process, unique clinical features, or investigation method, it should be added into the relevant columns in the mFMEA. This mFMEA process will collate and enrich the body of evidence for a specific clinical condition over time.

- You may attach a copy of the case report in the citation as a file attachment in an electronic database such as EndNote software. This will provide handy access to the references.

- The relevant main clinical features in the mFMEA, for example RUQ pain (or abdominal pain) can be extracted and reflected in the relevant Ishikawa diagram (see Figs. 1 and 3)

Advantages of weaving clinical cases into a mFMEA.

- mFMEA is a methodology that collates common, important, and critical (but rare) potential causes of a clinical condition.

- Studying clinical cases can reinforce clinicians' reasoning and diagnostic skills, and clinical experience.

- Clinicians may not have the opportunity to be involved in caring for patients with various potential "failure modes" of a clinical condition. Studying clinical cases and weaving them into a mFMEA will provide the opportunity to substantiate the lack of experience. 


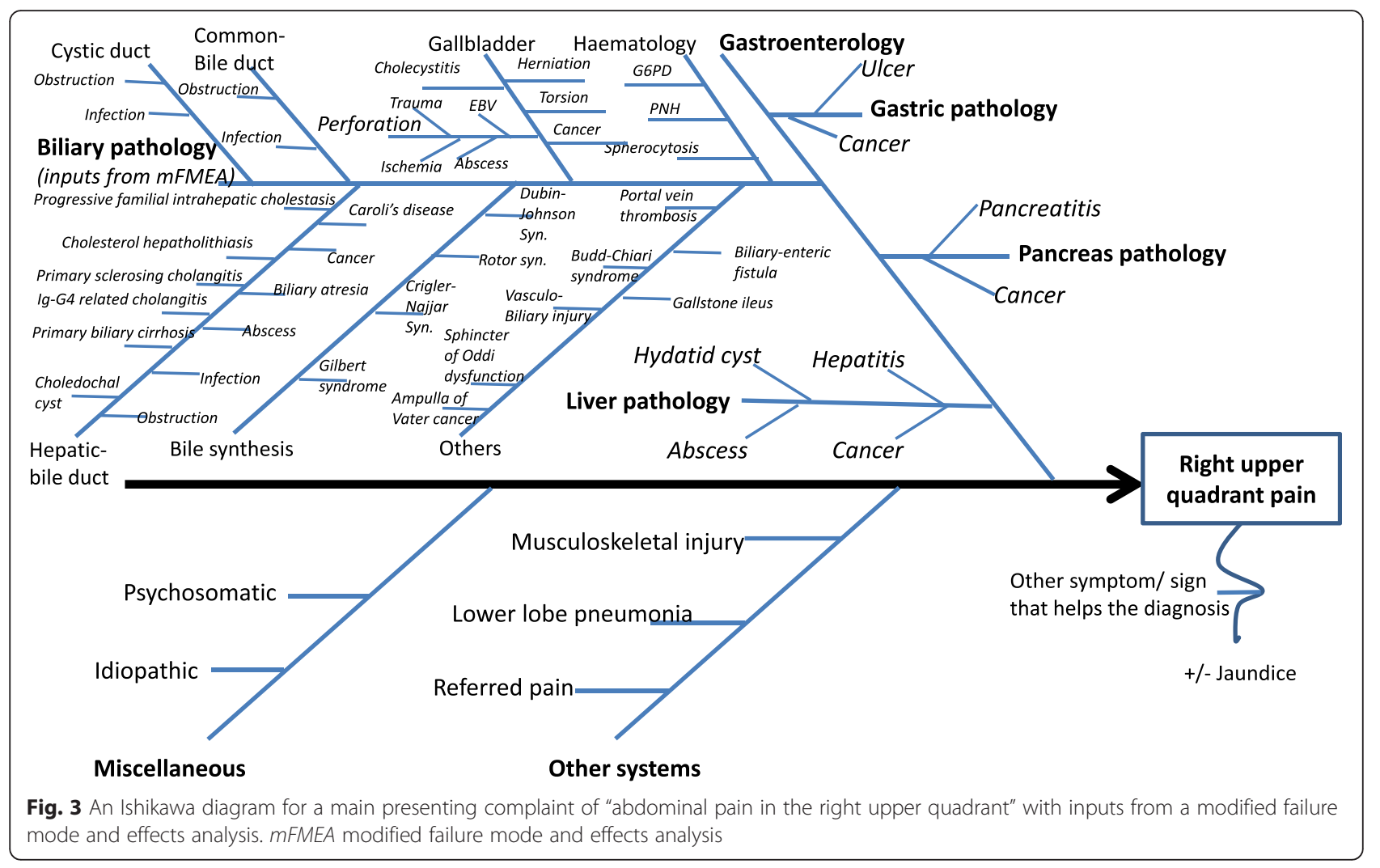

- Medical educators can select relevant clinical cases from a mFMEA to set the scenario for teaching a relevant topic.

- Medical educators should encourage medical students to attempt the approach of identifying the potential pathophysiology and diagnosis before providing the answer. It is acceptable to err in role playing the clinical case, and learn from the errors!

- Interactive teaching and learning using clinical cases are more engaging and interesting compared to sole didactic teaching.

- Medical educators can relate the clinical cases to a relevant Ishikawa diagram and mFMEA.

- GPs/family physicians may use a mFMEA to identify and manage critical but rare conditions. They may not need to go into the details of certain pathophysiological processes which may not be relevant to their role as a GP/family physician, for example different types of gallbladder herniation. By contrast, surgeons could be interested to find out the various gallbladder herniations and surgical interventions reported in the literature to compare and enhance their clinical experiences.

\section{Concluding remarks}

The mFMEA can be deployed as a tool to generate inputs for an Ishikawa diagram. Clinicians may apply the tool in their clinical reasoning process; while medical educators may select relevant clinical cases to set the scenarios to teach and facilitate a discussion among medical students, and relate the clinical cases back into a relevant mFMEA and Ishikawa diagram.

Competing interests

The author declares that he has no competing interests.

Author details

${ }^{1}$ Bathurst Rural Clinical School, Western Sydney University, Bathurst, NSW, Australia. ${ }^{2}$ School of Rural Health, University of Sydney, Orange, NSW, Australia.

${ }^{3}$ George Street Medical Practice, Bathurst, NSW, Australia.

Received: 18 August 2015 Accepted: 25 February 2016

Published online: 06 April 2016

References

1. Wong KC. Using an Ishikawa diagram as a tool to assist memory and retrieval of relevant medical cases from the medical literature. J Med Case Rep. 2011:5(1):120.

2. Wong KC, Woo KZ, Woo KH. Ishikawa Diagram. In: O'Donohue WT, Maragakis A, editors. Quality Improvement in Behavioral Health. New York: Springer Publishing Company; 2016.

3. Apkon $\mathrm{M}$ et al. Design of a safer approach to intravenous drug infusions: failure mode effects analysis. Qual Saf Health Care. 2004;13(4):265-71.

4. Rausand M, Hoylan A. System reliability theory: models, statistical methods, and applications. Hoboken, NJ: Wiley; 2004.

5. Asare K et al. Microscopic identification of possible Clonorchis/Opisthorchis infection in two Ghanaian women with undiagnosed abdominal discomfort: two case reports. J Med Case Rep. 2014;8(1):369.

6. Talley N, Martin C. Clinical gastroenterology. Sydney: MacLennan and Petty; 1996. 
7. Boer J, Boerma D, de Vries Reilingh T. A gallbladder torsion presenting as acute cholecystitis in an elderly woman: A case report. J Med Case Rep. 2011;5(1):588.

8. Dadzan E, Akhondi H. Choledochoduodenal fistula presenting with pneumobilia in a patient with gallbladder cancer: a case report. J Med Case Rep. 2012;6(1):61.

9. Sheridan D et al. Spontaneous acalculous gallbladder perforation. BMJ Case Rep. 2014. doi:10.1136/bcr-2014-206002.

10. Chalupa P, Kaspar M, Holub M. Acute acalculous cholecystitis with pericholecystitis in a patient with Epstein-Barr Virus infectious mononucleosis. Med Sci Monit. 2009;15(2):Cs30-3.

11. Donati $\mathrm{M}$ et al. An atypical presentation of intrahepatic perforated cholecystitis: a modern indication to open cholecystectomy. Report of a case. BMC Surg. 2014;14:6.

12. Kumar R. Non-operative management of gallbladder perforation after blunt abdominal trauma. J Surg Tech Case Rep. 2013;5(1):45-7.

13. Sharma RG et al. Spontaneous perforation of acalculous gallbladder: a case report. Indian J Surg. 2011;73(4):316-7

14. To H, Brough S, Pande G. Case report and operative management of gallbladder herniation. BMC Surg. 2015;15(1):72.

15. Garcia R et al. Parastomal herniation of the gallbladder. Hernia. 2005;9(4):397-9.

16. Rashid M, Abayasekara K, Mitchell E. A case report of an incarcerated gallbladder in a parastomal hernia. Int J Surg. 2010;23(2):8.

17. Rosenblum JK et al. Gallbladder torsion resulting in gangrenous cholecystitis within a parastomal hernia: findings on unenhanced CT. J Radiol Case Rep. 2013;7(12):21-5

18. St Peter S, Heppell J. Surgical images: soft tissue: incarcerated gallbladder in a parastomal hernia. Can J Surg. 2005;48(1):46

19. Benzoni C, Benini B, Pirozzi C. Gallbladder strangulation within an incisional hernia. Hernia. 2004:8(4):387-8.

20. Shirahama $M$ et al. Incisional hernia of gallbladder in a patient with gallbladder carcinoma: sonographic demonstration. J Clin Ultrasound. 1997; 25(7):398-400

21. Sirikci A, Bayram M, Kervancioglu R. Incisional hernia of a normal gallbladder: sonographic and CT demonstration. Eur J Radiol. 2002;41(1):57-9.

22. Paolino $L$ et al. Herniation of the gallbladder within a hernia of the abdominal wall associated with Mirizzi Syndrome. J Surg Case Rep. 2011; 2011(4):3

23. Trotta $\mathrm{M}$ et al. Complication of herniation through the abdominal wall. Surgery. 2013;154(5):1135-6.

24. Goldman G, Rafael A, Hanoch K. Acute acalculous cholecystitis due to an incarcerated epigastric hernia. Postgrad Med J. 1985;61(721):1017-8.

25. Sharma G, Askari R. Transdiaphragmatic intercostal herniation of the gallbladder. N Engl J Med. 2015;372(14), e19.

26. Losken A, Wilson B, Sherman R. Torsion of the gallbladder: a case report and review of the literature. Am Surg. 1997;63(11):975-8.

27. Goubault P et al. Gallbladder torsion within incisional hernia: an original cholecystitis. Springerplus. 2015;4(1):305

28. Koyanagi T, Sato K. Complete gallbladder torsion diagnosed with sequential computed tomography scans: a case report. J Med Case Rep. 2012;6(1):289.

29. Pezzoli A et al. Gallstone ileus treated with non-surgical conservative methods: a case report. J Med Case Rep. 2015;9(1):15.

30. Reisner R, Cohen J. Gallstone ileus. A review of 1001 cases. Am Surg. 1994 60:441-6.

31. Glenn F, Reed C, Grafe W. Biliary enteric fistula. Surg Gynecol Obstet. 1981; 153:527-31.

32. Malde S. Gallbladder agenesis diagnosed intra-operatively: a case report. J Med Case Rep. 2010;4:285.

33. Queiroz AB, de Miranda JS. Hydropic Gallbladder. New Engl J Med. 2011 364(20), e43.

34. Lemonick D, Garvin R, Semins H. Torsion of the gallbladder: a rare cause of acute cholecystitis. J Emerg Med. 2006;30(4):397-401.

35. Alevizos $L$ et al. Gallbladder volvulus as a cause of an acute abdomen in a 95-year-old patient. Am Surg. 2012;78(1):E47-8

36. Endeman H, Ligtenstein D, Oudemans-van SH. Spontaneous perforation of the cystic duct in streptococcal toxic shock syndrome: a case report. J Med Case Rep. 2008;2(1):338.

37. Shah S, Webber J. Spontaneous cystic duct perforation associated with acalculous cholecystitis. Am Surg. 2002;68:895-6.

38. Davies J, Burkitt M, Watson A. Ascending cholangitis presenting with Lactococcus lactis cremoris bacteraemia: a case report. J Med Case Rep. 2009;3(1):3.
39. Kang $H$, Moon S, Song I. A unique bleeding-related complication of sorafenib, a tyrosine kinase inhibitor, in advanced hepatocellular carcinoma: a case report. J Med Case Rep. 2014;8(1):72.

40. Qin L, Tang Z. Hepatocellular carcinoma with obstructive jaundice: diagnosis, treatment and prognosis. World J Gastroenterol. 2003;9:385-91.

41. Chin MW, Enns R. Hemobilia. Curr Gastroenterol Rep. 2010;12(2):121-9.

42. Yoshida J, Donahue PE, Nyhus LM. Hemobilia: review of recent experience with a worldwide problem. Am J Gastroenterol. 1987;82(5): $448-53$

43. Hurtado RM, Sahani DV, Kradin RL. Case records of the Massachusetts General Hospital. Case 9-2006. A 35-year-old woman with recurrent rightupper-quadrant pain. New Engl J Med. 2006;354(12):1295-303.

44. Meyers $W$ et al. Pathology of infectious diseases. Vol. 1. Helminthiases. Armed Forces Institute of Pathology: Washington; 2000.

45. Baldwin $\mathrm{M}$ et al. Ascaris lumbricoides resulting in acute cholecystitis and pancreatitis in the Midwest. Am J Gastroenterol. 1993;88(12):2119-21.

46. Arora R. Fibrolamellar hepatocellular carcinoma presenting as obstructive jaundice: uncommon presentation of a rare entity. Pol J Radiol. 2015;80: $168-71$

47. Ahmad SS et al. Cholangiocarcinoma presenting as hemobilia and recurrent iron-deficiency anemia: a case report. J Med Case Rep. 2010;4:133.

48. Peer A et al. Intrahepatic abscess due to gallbladder perforation. Abdom Imaging. 1995;20(5):452-5.

49. Yu Z-Y et al. Hepatolithiasis associated with intrahepatic heterotopic pancreas: a case report and literature review. Diagn Pathol. 2015;10(1):76.

50. Gu DH et al. Caroli's disease misdiagnosed as intraductal papillary neoplasm of the bile duct. Clin Mol Hepatol. 2015;21(2):175-9.

51. Zhang DY et al. Caroli's disease: a report of 14 patients and review of the literature. J Dig Dis. 2012;13(9):491-5.

52. El-Guindi MA et al. Urinary urobilinogen in biliary atresia: A missed, simple, and cheap diagnostic test. Hepatol Res. 2016;46(2):174-82.

53. Kaplan MM, Gershwin ME. Primary biliary cirrhosis. New Engl J Med. 2005: 353(12):1261-73

54. Danzi JT, Makipour H, Farmer RG. Primary sclerosing cholangitis. A report of nine cases and clinical review. Am J Gastroenterol. 1976;65(2):109-16.

55. Shu HJ et al. IgG4-related sclerosing cholangitis with autoimmune pancreatitis and periaortitis: case report and review of the literature. J Dig Dis. 2012;13(5):280-6.

56. De Both $\mathrm{A}$ et al. IgG4-related cholangitis: case report and literature review. Acta Gastroenterol Belg. 2015;78(1):62-4.

57. Nakanishi Y, Saxena R. Pathophysiology and diseases of the proximal pathways of the biliary system. Arch Pathol Lab Med. 2015;139(7):858-66.

58. Sadiq J, Nandi B, Lakhoo K. An unusual variant of choledochal cyst: a case report. J Med Case Rep. 2009;3:54.

59. Metcalfe MS, Wemyss-Holden SA, Maddern GJ. Management dilemmas with choledochal cysts. Arch Surg. 2003;138(3):333-9.

60. Yoo Y, Mun S. Synchronous double primary squamous cell carcinoma and adenocarcinoma of the extrahepatic bile duct: a case report. J Med Case Rep. 2015:9(1):116.

61. Bedoui R et al. Synchronous double cancer of the common bile duct. Am J Surg. 2011;201(1):1-2.

62. Ogawa A et al. Double cancers in the common bile duct: molecular genetic findings with an analysis of LOH. J Hepatobiliary Pancreat Surg. 2001;8(4): 374-8.

63. Bosma PJ et al. The genetic basis of the reduced expression of bilirubin UDP-glucuronosyltransferase 1 in Gilbert's syndrome. N Engl J Med. 1995; 333(18):1171-5.

64. Fretzayas A et al. Gilbert syndrome. Eur J Pediatr. 2012;171(1):11-5.

65. Mittal SK, Sinclair S. Criggler-Najjar syndrome. Report of a case. Indian J Pediatr. 1971;38(276):39-41.

66. Paulusma CC et al. A mutation in the human canalicular multispecific organic anion transporter gene causes the Dubin-Johnson syndrome. Hepatology. 1997;25(6):1539-42.

67. Renault M, Nowicki M. Persistent cholestasis following cholecystectomy: a case of Dubin-Johnson syndrome. J Pediatr. 2010;157(1):167.

68. Dubin IN, Johnson FB. Chronic idiopathic jaundice with unidentified pigment in liver cells; a new clinicopathologic entity with a report of 12 cases. Medicine (Baltimore). 1954:33(3):155-97.

69. Kagawa $T$ et al. Recessive inheritance of population-specific intronic LINEinsertion causes a Rotor syndrome phenotype. Hum Mutat. 2015; 36(3):327-32. 
70. Wolpert E et al. Abnormal sulfobromophthalein metabolism in Rotor's syndrome and obligate heterozygotes. N Engl J Med. 1977;296(19):1099-101.

71. Schiff L, Billing BH, Oikawa Y. Familial nonhemolytic jaundice with conjugated bilirubin in the serum. N Engl J Med. 1959:260(26):1315-8

72. Jadrijevic $S$ et al. Right hepatectomy due to portal vein thrombosis in vasculobiliary injury following laparoscopic cholecystectomy: a case report. J Med Case Rep. 2014;8(1):412.

73. Venkatesh P et al. Portal, superior mesenteric and splenic vein thrombosis secondary to hyperhomocysteinemia with pernicious anemia: a case report. J Med Case Rep. 2014;8:286.

74. Heinrich $\mathrm{S}$ et al. Right hemihepatectomy for bile duct injury following laparoscopic cholecystectomy. Surg Endosc. 2003;17:1494-5.

75. Okuda K, Kage M, Shrestha SM. Proposal of a new nomenclature for BuddChiari syndrome: hepatic vein thrombosis versus thrombosis of the inferior vena cava at its hepatic portion. Hepatology. 1998:28(5):1191-8.

76. Carvalho DT et al. Budd-Chiari syndrome in a 25-year-old woman with Behçet's disease: a case report and review of the literature. J Med Case Rep. 2011;5:52.

77. Romagnuolo J. Recent research on sphincter of Oddi dysfunction. Gastroenterol Hepatol (N Y). 2014;10(7):441-3.

78. Yaghoobi M, Romagnuolo J. Sphincter of Oddi dysfunction: updates from the recent literature. Curr Gastroenterol Rep. 2015;17(8):455

79. Alexiou K et al. Adenoma of the ampulla of Vater: a case report. J Med Case Rep. 2014;8(1):228.

80. Beger $\mathrm{H}$ et al. Tumor of the ampulla of Vater: experience with local or radical resection in 171 consecutively treated patients. Arch Surg. 1999; 134(5):526-32.

81. Estrella JS et al. Malignant solitary fibrous tumor of the pancreas. Pancreas. 2015;44(6):988-94.

82. de Gurrola GC et al. Kernicterus by glucose-6-phosphate dehydrogenase deficiency: a case report and review of the literature. J Med Case Rep. 2008; 2:146.

83. Moriyama $\mathrm{M}$ et al. A patient with paroxysmal nocturnal hemoglobinuria being treated with eculizumab who underwent laparoscopic cholecystectomy: report of a case. Surg Case Rep. 2015;1(1):57.

84. Lee JH, Moon KR. Coexistence of Gilbert syndrome and hereditary spherocytosis in a child presenting with extreme jaundice. Pediatr Gastroenterol Hepatol Nutr. 2014;17(4):266-9.

85. Rogal SS et al. A sweet source of abdominal pain. N Engl J Med. 2011; 364(18):1762-7.

\section{Submit your next manuscript to BioMed Central and we will help you at every step:}

- We accept pre-submission inquiries

- Our selector tool helps you to find the most relevant journal

- We provide round the clock customer support

- Convenient online submission

- Thorough peer review

- Inclusion in PubMed and all major indexing services

- Maximum visibility for your research

Submit your manuscript at www.biomedcentral.com/submit

C Biomed Central 